\title{
Essential Oil Composition from Twelve Varieties of Basil (Ocimum spp) Grown in Colombia
}

\author{
Amparo Viña and Elizabeth Murillo* \\ Departamento de Química, Facultad de Ciencias, Universidad del Tolima, Ibagué, Tolima, Colombia
}

\begin{abstract}
Foi analizada a composição do óleo esencial das partes aéreas de doze variedades de alfavaca (Ocimum spp). A análise foi feita por cromatografía gasosa-espectrometria de massas (CG-EM) e encontrou-se que dez das amostras foram caracterizadas pela presença de uma alta porcentagem de cinamato de metila (35-80\%), o qual define o químiotipo destas variedades. Somente uma das variedades apresentou o químiotipo cariofileno e mais uma o químiotipo linalol. As variedades "crespa morada", "virgen pequeña", e "virgen morada" apresentam o subtipo cinamato > linalol. A "blanca compacta" e a "crespa blanca" têm o subtipo cinamato de metila > linalol > 1,8-cineol. A "castilla morada" têm o subtipo cinamato de metila $>$ metil eugenol. O subtipo linalol $>$ cinamato de metila foi apresentado pela "verde de folhas grandes". Cariofileno > metil eugenol foi o subtipo da alfavaca "clavo". Cinamato de metila (constituindo mais do $62 \%$ do total do óleo esencial) foi o químiotipo para as outras variedades: "canela", "querendona morada", "dulce de castilla" e "zancona morada".
\end{abstract}

Essential oil compositions of aerial parts from twelve basil cultivars (Ocimum spp) were analysed by gas chromatography-mass spectrometry (GC-MS). Ten of them were characterized by the presence of a high percentage of methyl cinnamate (35-80\%), which defined the chemotype for these varieties. Only one presented the caryophyllene chemotype and another, the linalool chemotype. Three of the basils, "purple ruffles", "little virgin" and "purple virgin" exhibited the methyl cinnamate > linalool subtype. "White compact" and "white ruffles" showed the methyl cinnamate > linalool > 1,8-cineole subtype. Methyl cinnamate > methyl eugenol was the subtype for "purple castle". The variety "large green leaves" exhibited the linalool > methyl cinnamate subtype. Caryophyllene > methyl eugenol subtype was determined for "clove basil". The rest of the basils "cinnamon", "purple lovingly", "sweet castle" and "purple long-legged", belonged to the methyl cinnamate chemotype in which methyl cinnamate constituted more than $62 \%$ of the total essential oil content.

Keywords: Basil, Ocimum, methyl cinnamate, chemotype, essential oil

\section{Introduction}

Ocimum spp (basil) is an annual, aromatic, branched herb, 30 to $150 \mathrm{~cm}$ high. The plant has been used for medicinal purposes as a digestive stimulant and for treatment of insomnia and constipation. The oils of basil have been used principally in the food and cosmetic industries. ${ }^{1}$ They have wide applications as spices in sauces, confectionery products and sausages. Some of their volatile compounds have been suggested as allelopathic agents. ${ }^{2}$ The genus Ocimum undergoes abundant cross-pollination resulting in large numbers of subspecies and varieties, which differ in essential oil composition and morphological characteristics. Therefore, the taxonomy of the group is difficult. Basil oils from different geographical origins have been classified. ${ }^{3-13}$ According

* e-mail: emurillo8@hotmail.com to the chemical composition and geographical origin, Lawrence in 1980 and Boniface in 1987 classified them into three large groups: European type, Exotic or Reunion type and African type. ${ }^{14}$ On the basis of more than 200 analyses of oils extracted from $O$. basilicum, Lawrence ${ }^{8}$ established four essential oil chemotypes (methyl chavicol, linalool, methyl eugenol and methyl cinnamate) and also numerous subtypes. According to the biosynthetic origins of major compounds, he classified them as chemotypes with single or dual biosynthetic pathways. Other chemotypes such as eugenol-rich and thymol-rich in $O$. gratissimum, ${ }^{10,11,15}$ sesquiterpenes-rich in $O$. canum and $O$. sanctum, ${ }^{15}$ and terpinen-4-ol-rich, ${ }^{10}$ have been reported. However, there is little data available about the chemical characterization of the essential oils of the Ocimum species growing in Colombia, except those reported by Murillo and Viña. ${ }^{16}$ The purpose of the present work was to determine the essential oil chemotype of twelve basil 
varieties cultivated in Ibagué, Tolima- Colombia, in order to provide data, either for practical use or for basic research needs. This study will contribute to the knowledge of a local product that could improve the use of Colombian basil. The system of chemotype classification used was the one proposed by Grayer ${ }^{17}$ which is based on the combination of major chemical components rather than the sole dominant compound, defining a major component as one with content close to $20 \%$.

\section{Results and Discussion}

Table 1 gives the chemical composition found for the essential oils from 12 Ocimum varieties $(\mathrm{n}=1-12)$ indexed in Table 2. Sixty-eight components were detected, $45.6 \%$ of which are monoterpenes (19 hydrocarbons and 12 oxygenated); $35.3 \%$ are sesquiterpenes (18 hydrocarbons and 6 oxygenated); $7.4 \%$ are phenylpropanes (5); $2.9 \%$ partly identified (2); and $8.8 \%$ unidentified. Among all the constituents, the hydrocarbon terpenes were found in great variability.

"Little virgin" ( $n=7)$, "purple virgin" $(n=11)$, "white ruffle" ( $\mathrm{n}=10)$ and "large green leaves" ( $\mathrm{n}=8)$, which present higher variations in hydrocarbon terpenes than in oxygenated terpenes, are the varieties with the highest number of components (42 to 48). The varieties with the lowest number of constituents (13 to 16) are "clove" $(\mathrm{n}=12)$, "cinnamon" $(\mathrm{n}=1)$, "sweet castle" $(\mathrm{n}=4)$ and "purple ruffle" ( $\mathrm{n}=6)$; nevertheless, they present the highest variety of oxygenated components.

There are 26 major components of essential oils ( $1 \%$ or more of the total in at least one variety).

The most abundant components observed are: methyl cinnamate (present in all the varieties, 9-80\%); methyl chavicol (present in all the varieties, 0.4-12\%); methyl eugenol (absent in $\mathrm{n}=1$, ranging from $0.3-26 \%$ in the other varieties); linalool ( $0.8 \%$ in $\mathrm{n}=12$, ranging from $3-33 \%$ in the others); 1,8 -cineol ( $0.3 \%$ in $n=1$, absent in $n=12$, ranging from $2-15 \%$ in the remaining samples); terpinen4-ol (3-6\% in $\mathrm{n}=6,7,9,10,11)$; (E)-caryophyllene (absent in $\mathrm{n}=8$ and 10 and ranging from $0.3-43 \%$ in the others); and t-cadinol (absent in $\mathrm{n}=12,0.7-8.3 \%$ in the remaining samples). Moreover, components such as limonene, gcadinene and caryophyllene oxide occur in a high percentage in some varieties (from 2.5-13.9\%).

\section{Chemical profile}

Figures 1, 2 and 3 show the comparative chemical compositions of basil oils grouped into three compound families: phenylpropanoids, monoterpenes and sesqui- terpenes (according to the contents of the identified components (60) ). There appear to be three composition profiles: the phenylpropane $>$ monoterpene $>$ sesquiterpene profile (profile 1), the monoterpene $>$ phenylpropane $>$ sesquiterpene profile (profile 2) and the sesquiterpene $>$ phenylpropane $>$ monoterpene profile (profile 3 ).

\section{Varieties rich in phenylpropanoid}

The phenylpropanoid-rich varieties (Figure 1) are: "cinnamon" ( $\mathrm{n}=1)$, "purple lovingly" $(\mathrm{n}=2)$, "purple castle" $(\mathrm{n}=3)$, "sweet castle" $(\mathrm{n}=4)$, "purple long-legged" $(\mathrm{n}=5)$, "purple ruffle" ( $\mathrm{n}=6)$ and "little virgin" $(\mathrm{n}=7)$, listed in descending content of phenylpropanes (92-44.5\%). They show an increasing content of monoterpenes (6-34\%), as well as of sesquiterpenes (2-21\%). However, "sweet castle" $(n=4)$ varies from this behavior showing a content of $24 \%$ of monoterpenes and $2.4 \%$ of sesquiterpenes; "purple ruffle" $(\mathrm{n}=6)$ shows the lowest content of sesquiterpenes $(1.8 \%)$. This group of varieties is characterized by oxygenated terpene contents higher than those of the hydrocarbon terpenes.

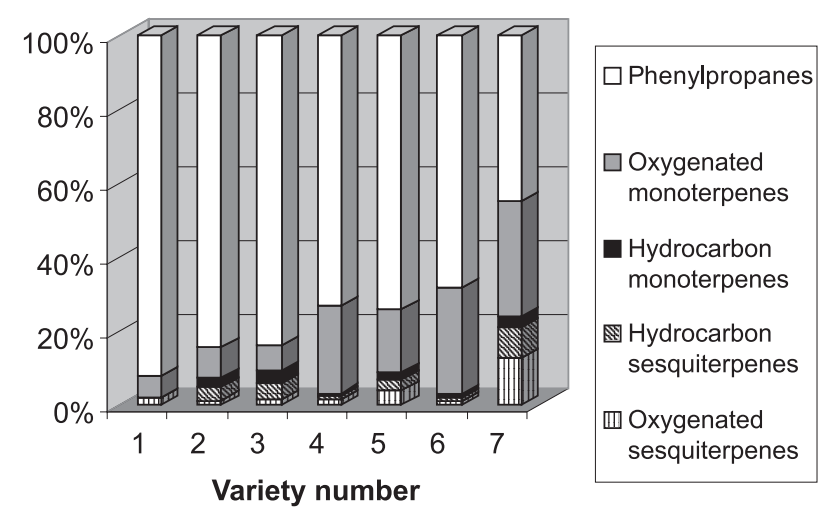

Figure 1. Comparative chemical composition of Colombian basil oils, based on the compound group classification. cinnamon (1), purple lovingly (2), purple castle (3), sweet castle (4), purple longlegged (5), purple ruffle (6), little virgin (7).

The chemical composition profile of the varieties of this group indicates a prevalence of the cinnamic acid biogenetic pathway, although the biogenetic pathway from mevalonic acid makes a high contribution in the profiles of two varieties $(n=6,7)$.

\section{Varieties rich in monoterpene}

The varieties that make up this group were identified as "profile 2". Comparison of the composition profiles of the varieties inside this group (Figure 2), shows a decreasing monoterpene content (50-44\%) and a small 
Table 1. Percentage composition of essential oils determined in 12 varieties of Ocimum collected in Ibagué

\begin{tabular}{|c|c|c|c|c|c|c|c|c|c|c|c|c|c|c|}
\hline \multirow[t]{2}{*}{ Compound } & \multirow{2}{*}{$\begin{array}{l}\text { K.I. }{ }^{a} \\
\text { DB-5 }\end{array}$} & \multirow[b]{2}{*}{ INNOVAX } & \multicolumn{12}{|c|}{$\begin{array}{c}\text { GC peak area }(\%) \\
n^{b}(\text { variety number) }\end{array}$} \\
\hline & & & 1 & 2 & 3 & 4 & 5 & 6 & 7 & 8 & 9 & 10 & 11 & 12 \\
\hline$\alpha$-Pinene & 936 & 1012 & - & - & 0.16 & - & - & - & 0.17 & - & 0.72 & 0.90 & 0.38 & - \\
\hline Camphene & 950 & 1075 & 0.18 & - & - & 0.25 & - & - & - & - & - & 0.11 & - & - \\
\hline Sabinene & 977 & 1115 & - & - & - & - & - & - & 0.16 & 0.74 & 0.30 & 0.60 & 0.36 & - \\
\hline$\beta$-Pinene & 983 & 1110 & - & 0.21 & 0.28 & 0.29 & - & 0.25 & 0.18 & - & 1.41 & 1.60 & 1.16 & - \\
\hline$\beta$-Myrcene & 991 & 1145 & - & - & 0.17 & 0.29 & 0.50 & - & 0.18 & 1.13 & 0.46 & 0.54 & 1.38 & - \\
\hline 1,4-Cineole & 1016 & 1188 & - & - & - & - & - & - & - & 0.17 & - & - & - & - \\
\hline$\alpha$-Terpinene & 1018 & 1170 & - & - & - & - & - & - & - & 0.33 & 0.26 & - & - & - \\
\hline p-Cymene & 1029 & 1198 & - & - & - & - & - & 0.32 & 0.40 & - & 0.40 & 0.19 & 0.16 & - \\
\hline Limonene & 1031 & 1180 & - & 0.26 & 0.40 & - & - & - & 0.30 & 3.62 & 0.60 & 0.70 & 0.75 & - \\
\hline 1,8-Cineole & 1034 & 1210 & 0.32 & 1.98 & 1.98 & 10.8 & 1.64 & 8.31 & 2.67 & 2.56 & 14.56 & 13.82 & 9.00 & - \\
\hline (Z)-Ocimene & 1037 & 1225 & - & - & 0.09 & - & - & - & - & 0.45 & - & - & - & - \\
\hline Trans-ocimene & 1050 & 1242 & - & 1.84 & 2.39 & - & 0.89 & - & 0.80 & 1.41 & 0.77 & 2.30 & 0.60 & - \\
\hline$\gamma$-Terpinene & 1062 & 1221 & - & - & - & - & - & 0.44 & 0.47 & 0.25 & 0.85 & 0.45 & 0.45 & - \\
\hline (Z)-Sabinene hydrate & 1068 & 1561 & - & - & - & - & 0.50 & - & 0.75 & - & - & 0.70 & 0.72 & - \\
\hline (Z)-Linalool oxide & 1074 & 1428 & - & - & - & - & - & - & - & 0.25 & - & - & - & - \\
\hline Isoterpinolene & 1084 & 1412 & - & - & - & - & 0.48 & - & 0.13 & 1.50 & 0.26 & 0.25 & 0.28 & - \\
\hline Fenchone & 1087 & 1391 & 0.15 & 0.85 & 0.85 & - & - & - & - & - & - & 0.19 & 0.70 & - \\
\hline Linalool & 1098 & 1537 & 4.44 & 4.62 & 3.05 & 12.6 & 13.3 & 16.53 & 20.29 & 33.03 & 20.6 & 15.87 & 19.85 & 0.85 \\
\hline Camphenol & 1110 & 1580 & - & - & - & - & - & 0.30 & - & - & - & - & - & - \\
\hline (Z)-Miroxide & 1131 & 1550 & - & 0.30 & 0.15 & - & - & - & - & - & - & 0.10 & - & - \\
\hline Camphor & 1143 & 1491 & 0.32 & - & - & - & - & 0.31 & - & 0.21 & - & 1.40 & 0.77 & - \\
\hline Phellandrene-8- $\alpha$-ol & 1165 & 1670 & - & - & - & - & - & - & - & - & 0.42 & 0.47 & 0.28 & - \\
\hline Terpinen-4-ol & 1177 & 1590 & - & - & - & - & - & 2.90 & 6.35 & 0.19 & 4.60 & 2.94 & 3.38 & - \\
\hline$\alpha$-Terpineol & 1190 & 1662 & - & 0.51 & 0.59 & 0.38 & 0.50 & 0.53 & 0.51 & 2.59 & 1.40 & 1.73 & 1.13 & - \\
\hline Methyl chavicol & 1195 & 1612 & 12.33 & 6.36 & 5.78 & 0.50 & 7.50 & 0.75 & 1.88 & 0.39 & 0.50 & 0.54 & 1.11 & 1.94 \\
\hline Caprylyl acetate & 1210 & 1429 & - & - & - & - & - & - & - & 0.16 & 0.17 & - & - & - \\
\hline Fenchyl acetate & 1223 & 1698 & - & - & - & - & - & - & - & - & - & 0.20 & 0.27 & - \\
\hline (Z)-Geraniol & 1228 & 1781 & - & - & - & - & - & - & - & 0.20 & - & - & - & - \\
\hline (E)-Geraniol & 1259 & 1847 & - & - & - & - & 0.40 & - & - & 0.80 & - & - & 1.13 & - \\
\hline Isobornyl acetate & 1290 & 1582 & 0.31 & - & - & - & - & - & - & 0.44 & 0.18 & 0.60 & 0.61 & - \\
\hline (Z)-Methyl cinnamate & 1301 & 1461 & 5.27 & 9.70 & 9.78 & 3.58 & 9.50 & 5.20 & 6.11 & 2.00 & 7.93 & 6.32 & 7.00 & 0.44 \\
\hline Limonene aldehyde & 1324 & 1678 & - & - & - & - & - & - & 0.22 & - & - & - & 0.36 & - \\
\hline$\alpha$-Terpinyl acetate & 1351 & 1685 & - & - & - & - & - & - & 0.18 & - & 0.80 & 0.25 & 0.27 & - \\
\hline$\alpha$-Cubebene & 1354 & 1445 & - & - & 0.07 & - & - & - & - & - & - & 0.10 & - & - \\
\hline Eugenol & 1356 & 2115 & - & - & - & - & - & - & - & 4.10 & - & - & - & 1.33 \\
\hline$\alpha$-Copaene & 1375 & 1477 & - & - & 0.14 & - & - & - & 0.18 & - & - & 0.17 & 0.36 & - \\
\hline (E)-Methyl cinnamate & 1379 & 2050 & 74.52 & 65.2 & 42.4 & 68.7 & 53.32 & 61.9 & 34.87 & 23.2 & 31.64 & 29.00 & 31.84 & 8.26 \\
\hline Methyl eugenol & 1407 & 1960 & - & 0.90 & 24.25 & 0.25 & 1.28 & 0.44 & 1.62 & 0.30 & 0.48 & 1.54 & 1.49 & 25.98 \\
\hline$\alpha$-Santalene & 1418 & 1450 & - & - & - & - & - & - & - & 0.30 & - & - & - & - \\
\hline (E)-Caryophyllene & 1420 & 1585 & - & 1.30 & 0.79 & 0.60 & 0.38 & 0.65 & 0.30 & - & - & 1.17 & 0.75 & 43.01 \\
\hline (E)- $\alpha$-Bergamotene & 1436 & 1536 & - & 0.43 & 0.51 & - & 0.59 & - & 0.37 & 0.60 & 0.91 & 3.19 & 0.27 & - \\
\hline Aromadendrene & 1438 & 1631 & - & - & - & - & - & - & - & 0.16 & - & - & - & - \\
\hline$\alpha$-Guaiene & 1439 & 1600 & - & 0.25 & 0.21 & - & 0.33 & - & 0.54 & 0.36 & 0.21 & 0.67 & 0.45 & - \\
\hline (E)- $\beta$-Farnesene & 1459 & 1650 & - & 0.43 & 0.55 & - & - & - & 0.33 & 0.31 & - & 0.22 & 0.71 & - \\
\hline$\beta$-Santalene & 1462 & 1439 & - & - & - & - & 0.27 & - & - & 0.83 & 0.36 & - & - & - \\
\hline$\beta$-Selinene & 1486 & 1725 & - & 0.69 & 0.65 & - & - & - & 1.13 & - & - & 1.10 & 0.79 & 1.41 \\
\hline \multicolumn{15}{|l|}{ Epibicyclo } \\
\hline sesquiphellandrene & 1490 & - & - & - & - & - & - & - & 0.39 & - & 0.19 & 0.23 & 0.27 & - \\
\hline N.I. & 1493 & - & - & - & 0.10 & - & - & - & - & 0.44 & - & - & - & - \\
\hline N.I. & 1495 & - & - & 0.60 & 0.44 & - & 0.78 & - & 0.80 & - & 0.40 & 1.15 & 1.19 & - \\
\hline$\alpha$-Selinene & 1497 & 1722 & - & - & 0.20 & - & - & - & 0.52 & 0.71 & 0.27 & 0.36 & 0.26 & - \\
\hline Germacrene B & 1500 & 1795 & - & 0.46 & 0.45 & - & - & - & 1.16 & 1.36 & 0.45 & 1.15 & 0.96 & - \\
\hline$\alpha$-Bisabolene & 1504 & 1680 & - & - & - & - & - & - & - & 1.00 & - & - & - & - \\
\hline$\delta$-Guaiene & 1505 & 1713 & - & - & - & - & 0.34 & - & 0.61 & 1.13 & 0.20 & 0.62 & 0.55 & - \\
\hline$\gamma$-Cadinene & 1512 & 1752 & 0.18 & - & 0.26 & 0.36 & 0.92 & 0.22 & 2.50 & 2.00 & 1.70 & 1.27 & 1.60 & - \\
\hline$\beta$-Sesquiphellandrene & 1524 & 1775 & - & - & - & - & - & - & - & - & - & 0.12 & - & - \\
\hline$\delta$-Cadinene & 1524 & 1751 & - & - & 0.11 & - & - & - & 0.16 & 0.70 & - & 0.10 & - & - \\
\hline Elemol & 1550 & 1984 & - & - & - & - & - & - & 0.31 & - & - & - & - & 0.52 \\
\hline $\mathrm{C} 15 \mathrm{H} 24$ & 1563 & & - & - & - & - & - & - & - & 0.32 & - & - & - & - \\
\hline N.I. & 1564 & & - & 1.90 & 1.60 & - & 1.65 & - & - & 1.10 & - & - & - & - \\
\hline N.I. & 1565 & & 0.22 & - & - & - & - & - & - & 0.31 & - & - & - & - \\
\hline Nerolidol & 1566 & 2030 & - & - & 0.08 & - & - & - & 0.60 & - & - & 0.17 & 0.32 & - \\
\hline N.I. & 1570 & & - & - & - & - & 1.15 & - & - & - & - & - & - & - \\
\hline Spatulenol & 1578 & 2035 & 0.16 & 0.10 & 0.18 & - & 0.43 & - & 1.05 & 0.15 & - & 0.28 & 0.25 & - \\
\hline Caryophyllene oxide & 1582 & 2008 & 0.59 & 0.21 & 0.25 & - & 0.10 & - & 0.48 & - & - & 0.31 & - & 13.94 \\
\hline Epicubenol & 1627 & 2025 & 0.30 & 0.15 & 0.25 & 0.20 & 0.39 & - & 1.93 & 1.10 & 0.90 & 0.73 & 0.90 & 0.36 \\
\hline$\tau$-Cadinol & 1648 & 2151 & 0.71 & 0.75 & 0.84 & 1.20 & 2.86 & 0.95 & 8.30 & 7.10 & 5.10 & 3.58 & 4.94 & - \\
\hline $\mathrm{C}_{15} \mathrm{H}_{26} \mathrm{O}$ & 1680 & & - & - & - & - & - & - & 0.10 & - & - & - & - & 0.90 \\
\hline N.I. & 1740 & & - & - & - & - & - & - & - & - & - & - & - & 1.06 \\
\hline Total compounds : 68 & & & 15 & 24 & 34 & 14 & 25 & 16 & 40 & 43 & 33 & 46 & 42 & 13 \\
\hline
\end{tabular}

${ }^{a}$ Kovat's Index. Experimentally determined percentages were calculated from the peak areas on the DB-5 column. Identification confirmed by GC-MS; ${ }^{\text {b }} 1$ (cinnamon), 2 (purple lovingly), 3 (purple castle), 4 (sweet castle), 5 (purple long-legged), 6 (purple ruffle), 7 (little virgin), 8 (large green leaves), 9 (white compact), 10 (white ruffle), 11 (purple virgin), 12 (clove). 
decrease in the sesquiterpene content (18-13.4\%) as well as an ever-increasing phenylpropanoid content (30-41.4\%), except $n=9$ which shows the lowest content of sesquiterpenes (10\%) and a high content of phenylpropanes $(41 \%)$. It could be said that the mevalonate pathway is the predominant biosynthetic route in this group. The essential oils belonging to this composition profile are oxygenated terpene-rich oils ( $\mathrm{n}=8, \mathrm{n}=9$ are the richest varieties, 48 and $48.7 \%$ respectively). From the contribution of the terpenoid content as a whole (both monoterpenes and sesquiterpenes) and the high content of oxygenated terpenes (43.6\%), "little virgin" ( $n=7)$, a phenylpropanoidrich variety (profile 1), also resembles the varieties named "profile 2".

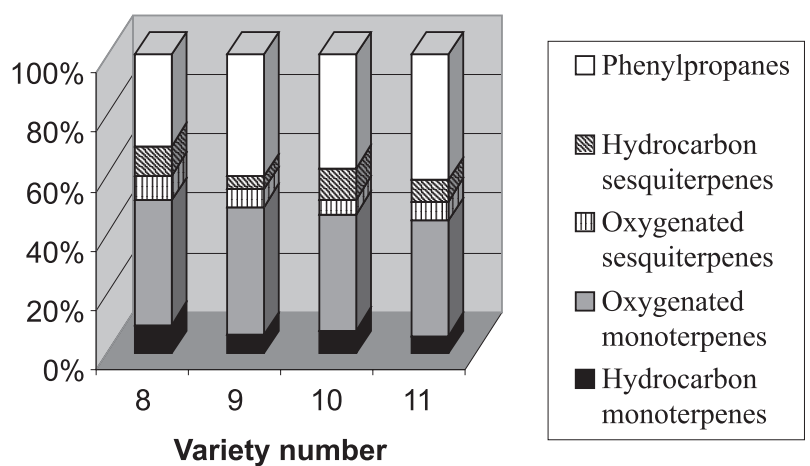

Figure 2. Comparative chemical composition of Colombian basil oils, based on the compound group classification. Large green leaves (8), white compact (9), white ruffle (10) purple virgin (11).

\section{Varieties rich in sesquiterpene}

Only one variety, "clove" $(\mathrm{n}=12)$, is sesquiterpenerich (59\%) (Figure 3), containing caryophyllene (43\%), caryophyllene oxide $(13.9 \%), \beta$-selinene $(1.4 \%)$, elemol $(0.5 \%)$ and epicubenol $(0.4 \%)$. Among the varieties in this investigation, this is the only variety characterized by a higher content of hydrocarbon terpenes (44.4\%) than of oxygenated terpenes $(15.7 \%)$.

\section{Chemotypes}

According to Grayer's chemotype classification system, the chemotypes for the 12 varieties utilized in this investigation were established (Table 2). Ten of them exhibited the "methyl cinnamate" chemotype with methyl cinnamate as the most abundant component. Methyl cinnamate, methyl eugenol and methyl chavicol, which are compounds belonging to the shikimate pathway, prevailed in $n=1,2,4$ and 5 and it could be said that only one biosynthetic pathway is operating for these oils.

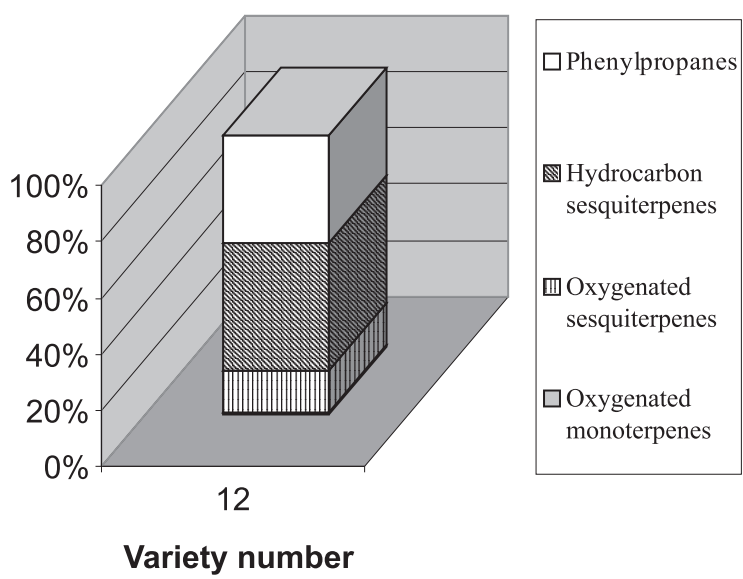

Figure 3. Chemical composition of Colombian clove basil (12), based on the compound group classification.

"Purple castle" ( $\mathrm{n}=3)$, presented two major components: methyl cinnamate $(52.2 \%)$ and methyl eugenol (24\%); therefore, the "methyl cinnamate > methyl eugenol" subtype was defined for this sample. Moreover, all the oils of this group (except oil from $n=4$ ) were characterized by relatively high contents of methyl chavicol (6-12\%). On the other hand, $n=4$ seemed somehow differentiated, having a considerable amount of 1,8-cineol (11\%) and linalool (13\%), belonging to the mevalonate pathway. The five remaining varieties can be ascribed to those plants in which essential oil constituents are produced by two different biosynthetic pathways: three varieties $(n=6,7,11)$ presented two major components, methyl cinnamate and linalool, and the "methyl cinnamate> linalool" subtype was defined for them; two varieties $(n=9,10)$ presented three major components which defined the "methyl cinnamate $>$ linalool > 1,8-cineol" subtype. Actually, methyl cinnamate has a biosynthetic origin from cinnamic acid whereas linalool and 1,8-cineol follow another biogenetic pathway from mevalonic acid.

About $80 \%$ of the total of the studied varieties had a high content of methyl cinnamate (35-80\%). Hence, extraction of essential oil from them could be important for the chemical industry. Distinct types of basil on the international market include European and Egyptian oils (two main types) and a Bulgarian or Cinnamon basil oil, rich in methyl cinnamate (as a source of methyl cinnamate). In 1987, Simon ${ }^{2}$ initiated a study to develop a methyl cinnamate rich basil, as this type was of the interest to the perfume industry. These authors increased the methyl cinnamate content (by 15\%); but, even so, they were lower than those reported for methyl cinnamate chemotypes in the present study.

From 9 cultivars of Ocimum basilicum, Hasegawa ${ }^{13}$ reported only one essential oil, from steam distillation, 
Table 2. Chemotype of 12 varieties of Ocimum detected in Ibagué

\begin{tabular}{|c|c|c|c|c|}
\hline Common name (spanish) & Scientific name & Chemotype & Subtype & $\mathrm{n}^{\mathrm{a}}$ \\
\hline Cinnamon (Canela) & O. micranthum & Methyl cinnamate & & 1 \\
\hline Purple lovingly (Querendona morada) & O. americanum & Methyl cinnamate & & 2 \\
\hline Purple castle (Castilla morada) & O. americanum & Methyl cinnamate & Methyl cinnamate $>$ methyl eugenol & 3 \\
\hline Sweet castle (Dulce de castilla) & O. basilicum & Methyl cinnamate & & 4 \\
\hline Purple long-legged (Zancona morada) & O. americanum & Methyl cinnamate & & 5 \\
\hline Purple ruffle (Crespa morada) & O. $s p$ & Methyl cinnamate & Methyl cinnamate $>$ linalool & 6 \\
\hline Little virgin (Virgen pequeña) & O. minimum & Methyl cinnamate & Methyl cinnamate $>$ linalool & 7 \\
\hline Purple virgin (Virgen morada) & O. minimum & Methyl cinnamate & Methyl cinnamate $>$ linalool & 11 \\
\hline White ruffle (Crespa blanca) & O. $s p$ & Methyl cinnamate & Methyl cinnamate $>$ linalool $>1,8$-cineol & 10 \\
\hline White compact (Blanca compacta) & O. basilicum & Methyl cinnamate & Methyl cinnamate $>$ linalool $>1,8$-cineol & 9 \\
\hline Large green-leaves (Verde de hojas grandes) & O. basilicum & Linalool & Linalool > Methyl cinnamate & 8 \\
\hline Clove (Clavo) & O. americanum & Caryophyllene & Caryophyllene> methyl eugenol & 12 \\
\hline
\end{tabular}

a Variety number.

rich in methyl cinnamate (74\%) which could be classified as "profile 1", according to this study. However, this oil presented qualitative and quantitative differences with respect to the components found for this profile. Lachowiczs ${ }^{4}$ identified both methyl cinnamate and linalool as the main components (ratio 1:1), together with small amounts of both methyl chavicol and 1,8-cineol, in hydrodistilled oil from a cinnamon basil. That hydrodistilled oil is similar to those called "profile 2" in our study, but these latter ones have methyl cinnamate to linalool in a 2:1proportion.

The "large green leaves" variety $(n=8)$ is the variety richest in monoterpenes (50\%) and presented a high content of linalool (33\%) which defined its chemotype as "linalool". The presence of methyl cinnamate as another main component $(25.2 \%)$ suggests a dual biosynthetic origin and defined the "linalool > methyl cinnamate" subtype for this variety. The essential oil composition of this variety of $O$. basilicum resembles the composition of two varieties reported by Lawrence ${ }^{18}$ for the same chemotype and genus. Pushpangadan and Bradu ${ }^{19}$ described the same chemotype, linalool $>$ methyl cinnamate, for $O$. basilicum var. Purpurascens. The "clove" variety $(n=12)$, of dual biosynthetic origin rich in sesquiterpenes, contains caryophyllene $(43 \%$, mevalonate pathway) and methyl eugenol (26\%, shikimate pathway). Therefore, this variety is characterized as "caryophyllene" chemotype and "caryophyllene > methyl eugenol" subtype. This "sesquiterpene" oil notably differs from those previously described by Sanda ${ }^{10}$ for $O$. canum and $O$. sanctum, which showed the same chemotype. On the other hand, it is important to mention that Lawrence ${ }^{15}$ described a variety of $O$. sanctum which he defined as "methyl eugenol" chemotype that presents caryophyllene as the second major component.

\section{Experimental}

\section{Plant material}

The 12 basil varieties used in this study are listed in Table 2, as well as the common and scientific names of each one. The aerial parts of the different basils utilized in this investigation were manually harvested, under optimal phytosanitary conditions, from plants growing on small farms located in urban and suburban areas of Ibagué, Tolima-Colombia. The samples were dried for a week (30$40^{\circ} \mathrm{C}$ ). Identification of the species was done by the Toli Herbarium of Tolima University, using the taxonomy keys determined by Moreno. ${ }^{20}$ Voucher specimens (00698100692) have been deposited in the Toli Herbarium.

\section{Essential oil extraction}

Leaves, flowers and stems of plant material $(50 \mathrm{~g})$ were subjected to distillation in water $(1: 20)$, in a modified Clevenger apparatus ${ }^{21}$ for $2 \mathrm{~h}$. The essential oils were dried over anhydrous $\mathrm{Na}_{2} \mathrm{SO}_{4}$, stored in a dark glass bottle and kept at $4^{\circ} \mathrm{C}$ until analysis.

\section{GC - MS analysis}

A Hewlet-Packard (HP) 5890 A Series II gas chromatograph interfaced to an HP 5972 MSD with a NBS75K and Wiley 138 Chem Station data system was used for MS identification of the GC components. GC conditions were: INNOVAX (Carbowax 20M, $0.25 \mu \mathrm{m}$ film thickness) column, $50 \mathrm{~m} \times 0.25 \mathrm{~mm}$ i.d. and HP-5 (polydimethylsiloxane, $0.25 \mu \mathrm{m}$ film thickness) $30 \mathrm{~m} \times 0.25$ i.d.; temperature program: $50{ }^{\circ} \mathrm{C}(5 \mathrm{~min}), 50-250{ }^{\circ} \mathrm{C}\left(4.5^{\circ} \mathrm{C} \mathrm{min}-1\right)$, $250^{\circ} \mathrm{C}$ (10 min); carrier gas, He at $78 \mathrm{kPa}$, linear velocity 
of $20 \mathrm{~cm} \mathrm{~min}^{-1} ; \mathrm{FID}$ at $250^{\circ} \mathrm{C}$; injection port split/ splitless (splitting ratio $1: 30$ ) at $250{ }^{\circ} \mathrm{C}$; injection volume, $0.5 \mu \mathrm{L}$ ( $20 \% \mathrm{v} / \mathrm{v}$ solution of essential oil in $\mathrm{CH}_{2} \mathrm{Cl}_{2}$ ). MS conditions were: ionization, $\mathrm{EI}$ at $70 \mathrm{eV} ; \mathrm{m} / \mathrm{z}$ range, $30-300$; scan rate $\sec ^{-1}$; ionization chamber at $180{ }^{\circ} \mathrm{C}$; transfer line at $280^{\circ} \mathrm{C}$.

Tetradecane was used as internal standard. Compounds were identified by comparison of their mass spectra and Kovat's retention indices with those of standards and with data reported in the literature..$^{22-23}$

\section{Conclusions}

Concerning the chemical composition of Ocimum varieties growing in Ibagué, Tolima- Colombia it could be stated that the "methyl cinnamate" chemotype was found for $80 \%$ of the varieties. The essential oils of Ocimum americanum, with the exception of "clove" basil, were rich in phenylpropanoids and a single biosynthetic origin is indicated for them as all of them showed a high methyl cinnamate content. "Clove", a variety of $O$. americanum, was the only basil of this region that was rich in sesquiterpenes; moreover, its chemotype indicates a dual biosynthetic origin. The essential oils of $O$. minimum had a dual biosynthetic origin which showed methyl cinnamate and linalool in a 2:1 proportion. Methyl cinnamate, linalool, 1,8-cineol, methyl chavicol, eugenol, methyl eugenol, caryophyllene, caryophyllene oxide and tcadinol were common compounds in all the oils of Ocimum varieties grown in Ibagué.

\section{Acknowledgements}

Financial support from the Comité Central de Investigaciones - Universidad del Tolima is gratefully acknowleged.

\section{References}

1. Charles, D. J.; Simon, J. E.; J. Am. Soc. Hort. Sci. 1990, 115, 458.

2. Simon, J. E.; Quinn, J.; Murray, R.G. In Advances in New Crops; Janick, J.; Simon, J.E., eds., Timber Press: Portland, OR, 1990, p. 484-489.

3. Lachowicz, K. J.; Jones, G. P.; Briggs, D. R.; Bienvenu, F. E.; Palmer, M. V.; Ting, S. S.; Hunter, M. ; J. Agric. Food Chem. 1996, 44, 877.
4. Lachowicz, K. J.; Jones, G. P.; Briggs, D. R.; Bienvenu, F. E.; Palmer, M. V.; Mishra, V.; Hunter, M. ; J. Agric. Food Chem. 1997, 45, 2660.

5. Venskutonis, R.; Poll, L.; Larsen, M. ; Flavour Fragr. J. 1996, 11,117 .

6. Grayer, R. J.; Bryan, S. E.; Veitch, N. C.; Goldstone, F. J.; Paton, A.; Wollenweber, E.; Phytochemistry 1996, 43, 1041.

7. Fleisher, A. ; J. Sci. Food Agric. 1981, 32, 11.

8. Lawrence, B. M.; A World Perspective. Proceedings of the 10 th International Congress of Essential Oils, Fragrances and Flavors, Washington, DC, USA 1986, Elsevier Science Publisher B.V. : Amsterdam, 1988, p. 161.

9. Marotti, M.; Piccaglia, R.; Giovanelli, E.; J. Agric. Food Chem. 1996, 44, 3926.

10. Sanda, K.; Koba, K.; Nambo, P.; Gaset, A.; Flavour Fragr. J. 1998, 13, 226.

11. Yusuf, M.; Begum, J.; Mondello, L.; Stagno d’ Alcontres, I.; Flavour Fragr. J. 1998, 13, 163.

12. Ravid, U.; Putievsky, E.; Katzir, I.; Lewinsohn, E.; Flavour Fragr. J. 1997, 12, 293.

13. Hasegawa, Y.; Tajima, K.; Toi, N.; Sugimura, Y.; Flavour Fragr. J. 1997, 12, 195.

14. Lawrence, B. M.; Perf. Flav. 1989, 14, 45.

15. Lawrence, B. M.; Proceedings of the 11th International Congress of Essential Oils, Fragrance and Flavors, New Delhi, India, 1989.

16. Murillo, E.; Viña, A.; Rev. Col. Quim. 1999, 28, 65.

17. Grayer, R. J.; Kite, G. C.; Goldstone, F. J.; Bryan, S. E.; Paton, A.; Putievsky, E.; Phytochemistry 1996, 43, 1033.

18. Lawrence, B. M.; Perf. Flav. 1995, 20, 35.

19. Pushpangadan, P.; Bradu, B. L. In Advances in Horticulture. Medicinal and Aromatic Plantas; Chadha, K. L. Gupta, R., eds.; Malhotra Publishing House: New Delhi, India, 1995, vol. 11, p. 627.

20. Moreno, B. G. V.; Tamayo, C. C. H.; Estrada, E. I.; Acta Agronómica, Universidad Nacional de Colombia 1987, 37, 34.

21. European Pharmacopoeia, $2^{\text {nd }}$ ed., Maisonneuve S.A.: Sainte Ruffin, France, 1980.

22. Adams, R. P.; Identification of Essential Oil Components by Gas Chromatography - Mass Spectroscopy, Allured Publishing Corporation: Carol Stream, IL, USA, 1995.

23. Kondjoyan, N.; Berdagué, J-L.; A Compilation of Relative Retention Indices for the Analysis of Aromatic Compounds, Edition du Laboratoire Flaveur: France, 1996.

Received: November 27, 2000

Published on the web: July 29, 2003 